\title{
Review on the quality of sediments from the stormwater drainage system in the urban area.
}

\author{
Nicole Nawrot ${ }^{1, *}$, and Ewa Wojciechowska ${ }^{1}$ \\ ${ }^{1}$ Faculty of Civil and Environmental Engineering, Gdańsk University of Technology, 11/12 \\ Narutowicza Str, 80-233 Gdansk, Poland
}

\begin{abstract}
The main task of the stormwater drainage system (SDS) is a safe drainage of rainwater and snowmelt from the urban area to the receiver. The flow of rain water in the drainage pipes is directly related with the formation of sediments in the whole stormwater system. In addition, pollutants from land runoff get adsorbed to the sediments. The sludge is mainly formed in those elements of SDS, wherein the flow conditions allow for sedimentation. This article provides an overview of the literature concerning the characteristics of sediments from SDS, with a particular focus on heavy metals in sediments deposited in the urban catchment area.
\end{abstract}

\section{Introduction}

Stormwater drainage systems (SDS) discharge rainwater or snowmelt runoff generated within the catchment to receivers - rivers, lakes, reservoirs [5]. SDS is equipped with devices to separate pollutants [4], which should be removed before rainwater is discharged to the receivers. These are stormwater inlets, sedimentation and retention tanks. In urban areas the amount of sludge produced in these devices is variable and usually difficult to estimate. This is primarily due to the lack of requirements for monitoring of the sediments. The most frequently analyzed and controlled elements are the concentrations of pollutants in stormwater which have limit concentrations while discharged to the receiver - soil or surface water [20]. The major sources of stormwater pollution in urban area are traffic, atmospheric dust, products of fuel combustion and to a lesser extent fertilizers and herbicides [1]. The suspended solids (SS) contained in runoff is the most important in terms of quantitative and qualitative evaluation of sediments. The SS fulfill an important role in the transportation of other pollutants. In storm sewage from urban area mineral SS dominate the organic SS. Mineral suspension constitutes about $80-99 \%$ of the total suspension. Characteristics of rainwater greatly influences the quality of deposits set aside in the SDS. Being aware of the presence of sediments in SDS it should be taken into account that the sediments must be periodically removed and properly managed or disposed in order to maintain proper operation of the system. Thus, it should be assessed to what extent the sediments from SDS are contaminated and whether they constitute a threat to the environment and human health. Unfortunately, in Poland there are neither quality standards

\footnotetext{
*Corresponding author: nawrotnicole@wp.pl
} 
for sediments from SDS nor technical guidelines for the treatment and disposal of sludge. Helpful in assessing the quality of sludge from SDS may be Geochemical criteria developed by the Polish Geological Institute PIB [7], ecotoxicological criteria (PEC Probable Effects Concentration) [6] and German LAWA classification 1997 (LanderArbeitsgemeinschaft Wasser) [19]. In this study, the data available for sediments from SDS and bottom sediments deposited in the retention tanks, receiving runoff from the urban area was collected. The speciation analysis of heavy metals (HM) in sediments, which is essential for assessing the scale of the potential hazard to the environment is also discussed. The article presents guidelines that can be useful for the study of sediments from SDS.

\section{Quantity and quality of sediments from SDS devices and retention tanks on the basis of literature data}

\subsection{Elements of SDS, where the sludge is formed}

The initial part of the SDS, which accumulates sediments are storm inlets with sediments tanks and local devices used to treat runoff - settling tanks and separators of petroleum substances [1]. A different part of the system are retention reservoirs, whose primaly function is flood protection. Sediments in reservoirs are formed as a result of the accumulation of autochthonous and allochthonous substances. While deposits from local storm sewage treatment facilities don't pose a direct danger to man, the retention tanks are public and often available to the fishery. Since most of the potentially hazardous contaminants (like HM) are deposited in sediments, it is important to assess the bioavailability of HM. Thus, apart from the total HM contents in sediments, speciation analysis is often used that allows for the quantitative determination of the various chemical forms in which the metals are bound in the bottom sediments [16].

\subsection{Quantitative assessment of sediments}

The amount of sludge produced in SDS depends on many factors, such as water content, particle size distribution, the efficiency of pretreatment. Quantification can often be affected by a material error, which creates a problem with designing of sedimentation tanks. The most effective way to assess the quantity of sludge is by far the observation of existing devices for at least one year time [1]. The data published in the literature is very divergent. Environnement Groupe Saint Dizier [1] estimated the quantity of SS removed annually from the surface areas of various development. The amount of SS discharged from urban centers during one year is at least $490[\mathrm{~kg} / \mathrm{ha} \cdot \mathrm{a}]$, a maximum of $4280[\mathrm{~kg} / \mathrm{ha} \cdot \mathrm{a}]$, an average of $1590[\mathrm{~kg} / \mathrm{ha} \cdot \mathrm{a}]$. For industrial areas, these values are at minimum of $450[\mathrm{~kg} / \mathrm{ha} \cdot \mathrm{a}]$, maximum 1700 [kg/ha.a], an average of 720 [kg/ha.a]. Dąbrowski [15] gives the number of SS discharged from one hectare of sealed surface by runoff for several catchment areas of the basin from 347 to $2340 \mathrm{~kg}$ suspension, on average 487 [kg/ha.a]. Still, load of SS discharged per year per one ha of sealed area doesn't reflect directly the amount of sludge in elements of SDS. Herold P. Guy already in 1970' presented the problems with sediments deposited in Urban areas (Washington 1970). Even then, it was recognized that the problem of control of the amount of sediments should be respected in the same level of importance as other environmental problems [10]. 


\subsection{Characteristics of sediment according to previous studies}

One of the few information about sediments deposited in the storm inlets comes from studies carried out in Bialystok [1,8]. Research was conducted with street inlets in areas with significant traffic. The analysis showed low usefulness of these deposits for recultivation due to high content of HM. Another study was performed in 1996-1998 [1]. Four inlets were selected, of different exposure to anthropogenic pollution. Three of them were at the streets of varying intensity of traffic and one at the bicycle path. The results were described by Grabarczyk in 1999 [8], who assessed that the sediments from street inlets have higher concentrations of substances of anthropogenic origin (eg. four times higher value of hydrocarbons in comparison to the inlet located on the bicycle path, similar disparities in case of $\mathrm{HM}$ ). The most contaminated sediments were recorded after snowmelt. Sludges from storm inlets predominantly consistied of mineral substances $[1,8]$. The largest share of the organic substances was recorded in the inlets, which accumulated a large amount of leaves and plant debris. Most oily deposits came from the grooves serving the drainage areas with significant traffic. Most total Kjeldahl nitrogen was observed in the inlets located on roadways with high traffic. In studies done by Krolikowski et al. [1] it was showed that $\mathrm{Zn}$ constituted of more than $68 \%$ of the total HM content. The analysis indicated that inlets can be divided into two groups which can be referred to as "low" or "highly loaded". Inlets highly loaded serve the catchments with significant traffic, city centers. The low loaded grooves are located within the residential districts of detached houses, serving partly pedestrian and cycling paths and streets with little traffic [1]. In reference to the cited classification (Tables 2-4) only the concentration of $\mathrm{Cd}$ was exceeded in sediments from storm inlets [1]. The study of sediments from sewage pretreatment devices was also performed by researchers from Bialystok [1]. Sludges from these devices are characterized by a higher water content in comparison to the inlets sediments. The concentration of total Kjeldahl nitrogen is also related to the nature of the basin. Like in the case of the sediments from storm inlets, $\mathrm{Zn}$ was dominating HM (representing close to $70 \%$ of the investigated metals). Krolikowski et al. (2005) determined the relevant statistical relationship between the concentration of $\mathrm{Pb}, \mathrm{Zn}, \mathrm{Cr}$ and $\mathrm{Cu}$. The contents of individual $\mathrm{HM}$ in the sediments was closely linked to each other (correlation coefficients within 0,85-0,97) [1]. Szyprowska et al. [9] studied physico-chemical properties and grain size of sludge produced in elements of SDS from the streets in the agglomeration of Warsaw in 2010-2011. They chose several devices located at the streets with high average daily traffic ADT over 25000 vehicles per day. In all samples the dominance of mineral SS above the organics was found $(73,1-97,1 \% \mathrm{dw})$. For the sample collected from the separator on the Siekierkowska route of ADT 100000 vehicles per day, exceeded concentrations of $\mathrm{Zn}$ and $\mathrm{Pb}$ were observed according to the geochemical classification (Table 2) and LAWA (Table 4). Szyprowska et al. (2012) confirmed that the same sediments accumulated in sedimentflotation devices contain approximately $80-90 \%$ of the hydrocarbons present in the runoff from roads. The evaluation of sediments coming from sedimentation tank located at Piekoszowska street in Kielce was conducted by Bak et al. (2012) [11]. Sludges were examined in the context of environmental hazards and the possibilities for their disposal. Sediment grain composition showed a high content of dust and clay fractions with a grain diameter less than $0,063 \mathrm{~mm}(65-72 \%)$, which is responsible for the sorption capacity of pollutants. $42 \%$ is the fraction of grain diameter of less than $0,025 \mathrm{~mm}$, the remaining fractions were sand and organic debris. Sediments showed the diverse content of HM. Large disparities between the samples taken at the inlet and outlet of the tank were observed for $\mathrm{Zn}$ (inlet 70,8 $\mathrm{mgZn} / \mathrm{kg} \mathrm{dw}$, outlet $750,9 \mathrm{mgZn} / \mathrm{kg} \mathrm{dw}$ ). The source of $\mathrm{Zn}$ are the products of weathered surface streets, broken discs and tires. The presence of carbonates was revealed, which in combination with a weakly alkaline $\mathrm{pH}$ of sediments suggests that metals are present in the forms of sparingly soluble compounds and, therefore 
weakly mobile in the environment. Salata and Bak (2015) [12] also performed an analysis of sediments of two retention tanks within the city of Kielce - open reservoir next to Witosa street (in use since 2003, $\mathrm{W}_{\text {IT }}$ - urbanized area) and closed reservoir next to Jesionowa street (in use since 2001, $\mathrm{J}_{\mathrm{ES}}$ - industrial area). The analysis of pollutant concentrations in the sediments of these tanks has shown that, in relation to the geochemical criteria (Table 2) the limit concentrations of $\mathrm{Zn}$ were exceeded in the sediment tank $\mathrm{W}_{\text {IT }}$, thereby classifying sludge from this tank in group II. For the sludges from tank $\mathrm{J}_{\mathrm{ES}}$ indicator metals concentrations were not exceeded, so the overall assessment of sediment ranks as the second class according to geochemical criteria. The analysis of Ecotoxicological PEL indicator (see Table 3) showed that the sediments $\mathrm{W}_{\text {IT }}$ and $\mathrm{J}_{\mathrm{ES}}$ were harmful to the environment and had a negative impact on living organisms, since the concentrations of $\mathrm{Pb}$ and $\mathrm{Zn}$ were exceeded. In $2012 \mathrm{Bak}$, Gorski et al. conducted a survey for the bottom sediments of the Suchedniow tank [13] - dam reservoir. The forests and arable lands constituted the greatest part of the catchment ( $45 \%$ and $18 \%$, respectively). The share of residential areas did not exceed 5\%. In the period 2009-2011 in the surrounding area the works related to the construction of the expressway S7 were performed. In the course of this work there was a significant increase in the volume of sediments deposited in the reservoir and the deterioration of water quality (high share of mineral SS). Concentrations of HM showed large spatial heterogeneity in the studied sediments. According to the geochemical classification (Table 2) Suchedniow tank sediments could be classified in class II for the content of $\mathrm{Cr}, \mathrm{Cu}, \mathrm{Ni}, \mathrm{Zn}$, class III because of $\mathrm{Pb}$ and class IV due to the $\mathrm{Cd}$ content. The share of $\mathrm{Pb}$ and $\mathrm{Cd}$ in the general contamination of sediments was greatest. Dabrowska (2009) studied speciation of HM in sediments from Kozlowa Gora tank. The highest concentrations of HM were found for $\mathrm{Zn}$ and according to geochemical criteria (Table 2) were classified as contaminated sediments. In addition, the value of the ecotoxicological indicator PEL (see Table 4) for Cd $(3,5 \mathrm{mg} / \mathrm{kg}$ ) was exceeded in two samples, for $\mathrm{Zn}(315 \mathrm{mg} / \mathrm{kg})$ for one sample and for $\mathrm{Pb}(91 \mathrm{mg} / \mathrm{kg})$ in sediments from all measurement points. Kozlowa Gora sediments were characterized by a low share of the ion-exchangeable fraction of metals. Most $\mathrm{Zn}$ and $\mathrm{Cr}$ were found in the fraction of practically insoluble compounds. $\mathrm{Cu}$ occurred mainly in the organic fraction, and $\mathrm{Pb}$ and nickel in conjunction with the carbonates. $\mathrm{Cd}$ was held in a fraction of hydrated iron oxides and manganese in the carbonate fraction depending on the measurement point. In 2006 K.V.Heal et al. characterized the quality and quantity of sediments deposited in three ponds and one wetland receiving urban surface run-off in Dunfermline, Scotland, UK. The aims of the study were to determine the correlations between the concentrations of HM and provide recommendations for the design and maintenance of sustainable urban drainage system ponds (with regards to sediments issues). The concentration of $\mathrm{Cr}, \mathrm{Cu}, \mathrm{Ni}, \mathrm{Zn}$ increased significantly in the sediments in all retention tanks from 1999 to 2002, though concentrations of most metals returned to 1999 values in 2003. The highest concentrations of $\mathrm{HM}$ were found for $\mathrm{Ni}$ (average value AV from 63,6 to $83,9 \mathrm{mg} / \mathrm{kg}$ ) for all ponds and according to geochemical criteria (Table 2) the sediments could be classified as II cleanlines class. Elevated concentrations of metals were also observed for Cr (AV 118 $\mathrm{mg} / \mathrm{kg}$ ) for one of the analyzed ponds in Duloch Park. Sediment depths varied within each pond, with sediment initially accumulating near inlets and in the primary basins [24]. Nine retention tanks receiving highway run-off in urbanized areas throughout the central and southern part of Florida were selected to investigate HM accumulation in bottom sediments. Sediment cores were sampled from each studied retention tank. The top layer of sediment core was the most hydrated. The moisture content in the top layer varied from a maximum of $76.4 \%$ at the North Miami Beach pond to a minimum of $49.6 \%$ at the New Smyrna pond. The greater part of metals (particularly $\mathrm{Pb}, \mathrm{Zn}, \mathrm{Cu}$ ) showed significantly higher concentrations in the top loose sediments. These metals amounted to more than $76 \%$ of 
total metals detected in urban and highway runoff, excluding iron. High content of metal concentrations reported for Fe (from $236 \mathrm{mg} / \mathrm{kg}$ (Clearwater, firm sediment) to $8367 \mathrm{mg} / \mathrm{kg}$ (Ocala, loose sediment), $\mathrm{Pb}$ (max concentration $1047 \mathrm{mg} / \mathrm{kg}$ - North Miami Beach), Zn (max concentration $538 \mathrm{mg} / \mathrm{kg}$ - Orlando) and $\mathrm{Cd}$ (max concentration $53 \mathrm{mg} / \mathrm{kg}-$ Fort Myers). According to the mentioned classification, the sediments should be classified as contaminated [25]. Comparison of heavy metal content of sludge from tanks shows Table 1.

Table 1 Summary of the contents of heavy metals in retention tanks $[\mathrm{mg} / \mathrm{kg}]$.

\begin{tabular}{|c|c|c|c|c|c|c|c|c|c|c|}
\hline \multirow{2}{*}{ Spot } & \multirow{2}{*}{$\begin{array}{l}\text { Type of } \\
\text { treatment } \\
\text { system }\end{array}$} & \multirow{2}{*}{\multicolumn{2}{|c|}{$\begin{array}{l}\text { Location/form } \\
\text { of sediment }\end{array}$}} & \multicolumn{6}{|c|}{ Sediments metals concentration } & \multirow{2}{*}{$\begin{array}{l}\text { Refe- } \\
\text { rences }\end{array}$} \\
\hline & & & & $\mathbf{Z n}$ & $\mathbf{P b}$ & $\mathbf{C u}$ & $\mathrm{Ni}$ & $\mathbf{C r}$ & Cd & \\
\hline \multirow{7}{*}{$\begin{array}{l}\vec{T} \\
\text { ज़ } \\
\stackrel{0}{0}\end{array}$} & $\begin{array}{c}\text { Inlets in } \\
\text { Białystok }\end{array}$ & \multicolumn{2}{|c|}{ Inlet low loaded } & $\begin{array}{l}28.1- \\
167.0 \\
\end{array}$ & $\begin{array}{r}0- \\
32.5 \\
\end{array}$ & $\begin{array}{l}2.5- \\
22.2 \\
\end{array}$ & - & $\begin{array}{l}3.2- \\
9.4 \\
\end{array}$ & - & \multirow[b]{2}{*}{ [1] } \\
\hline & $\begin{array}{c}\text { Inlets in } \\
\text { Białystok }\end{array}$ & \multicolumn{2}{|c|}{$\begin{array}{c}\text { Inlet highly } \\
\text { loaded }\end{array}$} & $\begin{array}{l}30.0- \\
429.0\end{array}$ & $\begin{array}{c}0- \\
76.6\end{array}$ & $\begin{array}{l}2.6- \\
44.6\end{array}$ & - & $\begin{array}{l}4.1- \\
20.2\end{array}$ & - & \\
\hline & $\begin{array}{c}\text { Elements of } \\
\text { SDS Warsaw }\end{array}$ & \multicolumn{2}{|c|}{$\begin{array}{c}\text { Siekierkowska } \\
\text { route }\end{array}$} & 1142 & 116.4 & - & - & - & - & [9] \\
\hline & Retention & \multicolumn{2}{|c|}{ Inlet } & 70.8 & 1.0 & 9.5 & - & - & 0.1 & \multirow[b]{2}{*}{ [11] } \\
\hline & $\begin{array}{c}\text { tank (open) } \\
\text { Kielce }\end{array}$ & \multicolumn{2}{|c|}{ Outlet } & 750.9 & 4.4 & 2.6 & - & - & 0.2 & \\
\hline & $\begin{array}{c}\text { Suchedniow } \\
\text { tank }\end{array}$ & \multicolumn{2}{|c|}{ Retention tank } & $\begin{array}{l}177.5- \\
216.9 \\
\end{array}$ & $\begin{array}{l}59.4- \\
110.0 \\
\end{array}$ & $\begin{array}{l}26.4- \\
42.9 \\
\end{array}$ & $\begin{array}{l}27.3- \\
31.4 \\
\end{array}$ & $\begin{array}{l}37.4- \\
63.9 \\
\end{array}$ & $\begin{array}{l}5.0- \\
10.7 \\
\end{array}$ & [13] \\
\hline & $\begin{array}{c}\text { Kozlowa } \\
\text { Gora tank }\end{array}$ & \multicolumn{2}{|r|}{ Tank } & $84-627$ & $\begin{array}{l}41- \\
121\end{array}$ & $\begin{array}{l}2.8- \\
11.2\end{array}$ & $\begin{array}{l}3.1- \\
16.1\end{array}$ & $\begin{array}{l}1.7- \\
15.4\end{array}$ & $\begin{array}{l}0.8- \\
7.6\end{array}$ & [14] \\
\hline \multirow{4}{*}{ 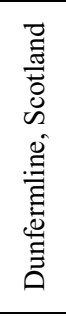 } & $\begin{array}{l}\text { Halbeatth } \\
\text { Pond }\end{array}$ & \multirow{4}{*}{ 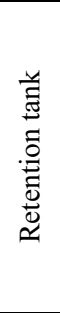 } & $\begin{array}{l}1 \text { inlet. } \\
1 \text { outlet }\end{array}$ & $\begin{array}{c}5.5- \\
151.3 \\
\end{array}$ & $\begin{array}{c}0- \\
57.8\end{array}$ & $\begin{array}{l}9.6- \\
28\end{array}$ & $\begin{array}{l}14.9- \\
111.7\end{array}$ & $\begin{array}{c}4.9- \\
136.5 \\
\end{array}$ & $\begin{array}{c}0- \\
0.75\end{array}$ & \multirow{4}{*}[25]{} \\
\hline & Linburn Pond & & $\begin{array}{c}4 \text { inlets. } 1 \\
\text { outlet }\end{array}$ & $\begin{array}{l}20.6- \\
199.4\end{array}$ & $\begin{array}{c}5.8- \\
45\end{array}$ & $\begin{array}{l}5.6- \\
36.2 \\
\end{array}$ & $\begin{array}{l}28.6- \\
108.2\end{array}$ & $\begin{array}{c}0- \\
165.2 \\
\end{array}$ & $\begin{array}{c}0- \\
0.64 \\
\end{array}$ & \\
\hline & Pond 7 & & $\begin{array}{c}3 \text { inlets. } 1 \\
\text { outlet }\end{array}$ & $\begin{array}{l}52.2- \\
101.8\end{array}$ & $\begin{array}{l}8.7- \\
27.6\end{array}$ & $\begin{array}{l}9.9- \\
22.7\end{array}$ & $\begin{array}{l}27.9- \\
145.3\end{array}$ & $\begin{array}{c}8.0- \\
128.0\end{array}$ & $\begin{array}{c}0- \\
0.81\end{array}$ & \\
\hline & Wetland pond & & $\begin{array}{c}2 \text { inlets. } 1 \\
\text { outlet }\end{array}$ & $\begin{array}{c}50- \\
136.2 \\
\end{array}$ & $\begin{array}{l}5.4- \\
39.8 \\
\end{array}$ & $\begin{array}{l}10.0- \\
24.8 \\
\end{array}$ & $\begin{array}{c}6.1- \\
121.1 \\
\end{array}$ & $\begin{array}{c}0- \\
178.7 \\
\end{array}$ & $\begin{array}{c}0- \\
1.33 \\
\end{array}$ & \\
\hline \multirow{22}{*}{$\frac{\pi}{\frac{\pi}{2}}$} & \multirow{2}{*}{ Orlando } & \multirow{22}{*}{ 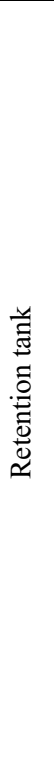 } & loose & 538 & 1025 & 73 & 29 & 68 & 3 & \multirow{22}{*}{ [26] } \\
\hline & & & firm & 43 & 171 & 14 & 19 & 37 & 4 & \\
\hline & \multirow{2}{*}{ Tampa } & & loose & 56 & 94 & 13 & 12 & 30 & 2 & \\
\hline & & & firm & 12 & 18 & 2 & 9 & 17 & 2 & \\
\hline & \multirow{2}{*}{ New Smyrna } & & loose & 20 & 124 & 7 & 44 & 19 & 31 & \\
\hline & & & firm & 2 & 36 & 3 & 17 & 5 & 13 & \\
\hline & Fort Mvers & & loose & 13 & 192 & 7 & 82 & 28 & 53 & \\
\hline & Fort Myers & & firm & 2 & 64 & 3 & 30 & 17 & 16 & \\
\hline & Ocala & & loose & 286 & 371 & 31 & 56 & 112 & 2 & \\
\hline & Ocala & & firm & 22 & 33 & 5 & 17 & 15 & 1 & \\
\hline & & & loose & 79 & 237 & 22 & 52 & 128 & 34 & \\
\hline & Palm вау & & firm & 4 & 26 & 2 & 6 & 11 & 3 & \\
\hline & Melbourne & & loose & 71 & 159 & 46 & 72 & 55 & 1 & \\
\hline & Melbourne & & firm & 5 & 40 & 4 & 59 & 7 & 1 & \\
\hline & Clearwater & & loose & 91 & 119 & 16 & 37 & 41 & 1 & \\
\hline & & & firm & 8 & 105 & 5 & 39 & 11 & 1 & \\
\hline & North Miami & & loose & 291 & 1047 & 33 & 82 & 71 & 4 & \\
\hline & Beach & & firm & 10 & 113 & 6 & 57 & 38 & 1 & \\
\hline & Average & & loose & 161 & 374 & 28 & 52 & 61 & 15 & \\
\hline & Average & & firm & 12 & 67 & 5 & 28 & 18 & 5 & \\
\hline & SD & & loose & 176 & 384 & 21 & 24 & 38 & 20 & \\
\hline & & & Firm & 13 & 52 & 4 & 20 & 12 & 6 & \\
\hline
\end{tabular}




\subsection{Speciation analysis of HM}

The greater part of HM that end up in water is bound and transported with the SS, which leads to deposition of metals with sediments in retention tanks. Contaminants in sediments have a negative impact on the aquatic ecosystem and, indirectly, on the components of the biotope and biocenosis as well as humans. The concentrations of harmful substances in the sediments are much higher than in water. HM are not permanently fixed in bottom sediments. Often metals show susceptibility to migrate from bottom sediments into the water column, causing recontamination. This phenomenon is called the mobility of HM and depends on the form in which the metal is present and physicochemical conditions. Some of the factors which determine the forms of metals speciation in sediments are $\mathrm{pH}$, redox potential value or ionic strength [16]. In acidic soils and sediments $(\mathrm{pH}=5,5)$ labile ionic form dominate, while in neutral $(\mathrm{pH}=6,6-7,2)$ and alkaline ( $\mathrm{pH}$ above 7,2) soils and sediments less mobile, difficult soluble hydroxy oxygen forms are dominating [16]. Changing environmental conditions, acidity, redox potential, the concentrations of inorganic and organic ligands affect the mobility and bioavailability of the metal [17]. Speciation analysis is specifying the forms of the presence of HM and their quantitative determination, using selective extraction method, and (often) sequential extraction. The results of speciation analysis lead to the conclusion about the origin of the trace elements, their occurrence, as well as the possibility of migration in the environment.

\section{The sediments classifications}

Based on the analysis of the literature reports several criteria have been presented that may be used for the classification of sediment from SDS.

\subsection{Geochemical criteria developed by the Polish Geological Institute PIB}

The geochemical classification for aquatic sediment was first presented by Bojakowska and Sokołowska (1998) [7]. This classification presents three classes of sediment cleanliness. The limit value for the quality class is determined using the principle that the contents of anomalous element in the environment takes concentration higher than the sum of the average content of this element and two standard deviations laid down for the population studied. Additionally, geochemical classification takes into account the geochemical background for individual elements.

Table 2 Classification of sediments on the basis of geochemical criteria ppm [mg/kg] [7].

\begin{tabular}{|c|c|c|c|c|}
\hline \multirow{2}{*}{ Metal } & \multirow{2}{*}{ Geochemical background } & \multicolumn{3}{|c|}{ Cleanliness class } \\
\cline { 3 - 5 } & & I & II & III \\
\hline Zinc $(\mathrm{Zn})$ & 48 & $<200$ & $<1000$ & $<2000$ \\
\hline Lead $(\mathrm{Pb})$ & 10 & $<50$ & $<200$ & $<500$ \\
\hline Copper $(\mathrm{Cu})$ & 6 & $<20$ & $<100$ & $<200$ \\
\hline Nickel $(\mathrm{Ni})$ & 5 & $<30$ & $<50$ & $<100$ \\
\hline Chrome $(\mathrm{Cr})$ & 5 & $<20$ & $<100$ & $<500$ \\
\hline Cadmium $(\mathrm{Cd})$ & $<0.5$ & $<1$ & $<5$ & $<20$ \\
\hline Mercury $(\mathrm{Hg})$ & $<0.05$ & $<0.1$ & $<0.5$ & $<1.0$ \\
\hline
\end{tabular}




\subsection{Ecotoxicological classification}

Ecotoxicological studies allow for assessment of the impact of pollutants in sediments (heavy metal compounds, radionuclides, hydrophobic organic compounds) on elimination of ecologically important groups of benthic organisms. Ecotoxicological classifications are used to estimate the exposure of biocenoses of bottom sediments in water reservoirs to the presence of substances accumulating in sediments, (also undergoing desorption to the aqueous phase). Worldwide there have been many methods developed to determine quality standards (SQG - Sediment Quality Guidelines) [6], which are used to assess the risk caused by the presence of organic compounds and HM in sediments. Some of the indicators are based on empirical methods - these are indicators ERL and ERM (Effects Range-Low, Effects Range-Median [21]), TEL and PEL (Threshold Effects Level, Probable Effects Level [23]), SLC (Screening Level Concentration [22]). Examples of the described indicators for PAHs are presented in the Table below.

Table 3 SQG values for selected polycyclic aromatic hydrocarbons [6].

\begin{tabular}{|c|c|c|c|c|c|}
\hline \multirow{2}{*}{ Compound } & \multicolumn{5}{|c|}{ SQG $\boldsymbol{\mu k g}$} \\
\cline { 2 - 6 } & \multicolumn{2}{|c|}{ Level of threshold effects } & \multicolumn{2}{c|}{ Level of adverse effects } \\
\cline { 2 - 6 } & SLC & TEL & ERL & PEL & ERM \\
\hline Anthracene & 160 & 50 & 90 & 240 & 1100 \\
\hline Naphthalene & 410 & 30 & 160 & 390 & 2100 \\
\hline Benzo[a]pyrene & 400 & 90 & 430 & 760 & 1600 \\
\hline
\end{tabular}

\subsection{LAWA classification from 1997 (Lander-Arbeitsgemeinschaft Wasser)}

It was developed in cooperation with the Federal Environment Agency (Umweltbundesamt) in Germany in 1997 [19]. This classification divides the water, bottom sediments and SS into seven classes of purity, depending on the degree of contamination of these components of aquatic ecosystems with HM. Class I refers to uncontaminated sediment, without anthropogenic interference. Class I-II - sediments unpolluted or with very small anthropogenic interference. Class II corresponds to moderately polluted sediments, and it is a reference for the other levels of pollution. Class II-III - twice the Class II - defines moderate to significant contamination of sediments, Class III - four times Class II - defines significant pollution, class III-IV - eight times Class II - refers to a very strong pollution, Class IV - means more than eight times exceeding class II - is an ultimate pollution. Comparative value is the average contents of $\mathrm{HM}$ expressed in $\mathrm{mg} / \mathrm{kg}$.

Table 4 The concentration of various HM in $\mathrm{mg} / \mathrm{kg}$ for each class of sediments classification LAWA [19].

\begin{tabular}{|l|c|c|c|l|l|l|c|}
\hline \multirow{2}{*}{ Metal } & \multicolumn{7}{|c|}{ Purity class } \\
\cline { 2 - 8 } & I & I-II & II $^{*}$ & II-III & III & III-IV & IV \\
\hline Zinc $(\mathrm{Zn})$ & $\leq 100$ & $\leq 150$ & $\leq 200$ & $\leq 400$ & $\leq 800$ & $\leq 1600$ & $>1600$ \\
\hline Lead $(\mathrm{Pb})$ & $\leq 25$ & $\leq 50$ & $\leq 100$ & $\leq 200$ & $\leq 400$ & $\leq 800$ & $>800$ \\
\hline Copper $(\mathrm{Cu})$ & $\leq 20$ & $\leq 40$ & $\leq 60$ & $\leq 120$ & $\leq 240$ & $\leq 480$ & $>480$ \\
\hline Nickel $(\mathrm{Ni})$ & $\leq 30$ & $\leq 40$ & $\leq 50$ & $\leq 100$ & $\leq 200$ & $\leq 400$ & $>400$ \\
\hline Chrome $(\mathrm{Cr})$ & $\leq 80$ & $\leq 90$ & $\leq 100$ & $\leq 200$ & $\leq 400$ & $\leq 800$ & $>800$ \\
\hline Cadmium $(\mathrm{Cd})$ & $\leq 0.3$ & $\leq 0.6$ & $\leq 1.2$ & $\leq 2.4$ & $\leq 4.8$ & $\leq 9.6$ & $>9.6$ \\
\hline Mercury $(\mathrm{Hg})$ & $\leq 0.2$ & $\leq 0.4$ & $\leq 0.8$ & $\leq 1.6$ & $\leq 3.2$ & $\leq 6.4$ & $>6.4$ \\
\hline
\end{tabular}




\section{Conclusions}

1. Quality of sediments deposited in SDS should be monitored and subjected to environmental classification. It is of relevance to develop standards dealing specifically with this type of sludge. The priority should be to determine the exact directions of management and disposal.

2. The most restrictive of the existing sediments quality criteria appear to be eco-defined indicators PEL and TEL.

3. Speciation analysis of HM in sediments from retention tanks allows to determine metals mobility and lability and to assess their susceptibility to migration from the sediments into the water column, and vice versa.

\section{References}

1. A.Królikowski, K.Grabarczyk, J. Gwoździej-Mazur, A.Butarewicz, Osady powstajace w obiektach systemu kanalizacji deszczowej (Monografia PAN, nr 35, Lublin, 2005)

2. H.Obarska-Pempkowiak, M.Gajewska, E.Wojciechowska, Hydrofitowe oczyszczanie wód i ścieków (Wydawnictwo Naukowe PWN, Warszawa 2010)

3. A.Kabata-Pendias, H.Pendias, Biogeochemia pierwiastków śladowych (Wydawnictwo Naukowe PWN, Warszawa, 1993)

4. E.Wojciechowska, M.Gajewska, N.Żurkowska, M.Surówka, H.Obarska-Pempkowiak, Zrównoważone systemy gospodarowania woda deszczowa (Wydawnictwo Politechniki Gdańskiej, Gdańsk, 2015)

5. Z.Suligowski, A.Tuszyńska, Problemy zagospodarowania wód opadowych w Polsce. Kanalizacja ogólnospławna, http://retencja.pl

6. R.Kalinowski, M.Załęska-Radziwiłł, Ochrona Środowiska i Zasobów Naturalnych 40 (2009)

7. I.Bojakowska, G.Sokołowska, Przegląd Geologiczny 46, 1 (1998)

8. K.Grabarczyk, Wplyw ścieków deszczowych na zawartość zanieczyszczeń w osadach zatrzymywanych $w$ urzadzeniach kanalizacji deszczowej systemu rozdzielczego, rozprawa doktorska (Politechnika Białostocka, Białystok, 1999)

9. E.Szyporowska, H. Sawicka-Siarkiewicz, A. Nechay, Ochrona Środowiska i Zasobów Naturalnych 54 (2012)

10. H.P. Guy, Sediment Problems in Urban Areas (Water in the Urban Environment, Washington, 1970)

11. Ł.Bąk, L.Dąbek, E.Ozimina, A.Sałata, Ocena jakości osadów pochodzacych ze zbiornika otwartego miejskiej kanalizacji deszczowej $w$ kontekście zagrożenia dla środowiska oraz możliwości ich zagospodarowania (Monografia PAN, nr 100, Lublin, 2012)

12. A.Sałata, Ł.Bąk, Proceedings of ECOpole 9, 1 (2015)

13. Ł.Bąk, J.Górski, A.Rabajczyk, M.Szwed, Proceedings of ECOpole (2015)

14. L.Dąbrowska, Ochrona Środowiska i Zasobów Naturalnych 49 (2011)

15. W. Dąbrowski, Gaz, Woda i Technika Sanitarna 6 (2001)

16. J.Pawłowski, M.Rozental, A.Drzewińska, S.Neffe, Biuletyn WAT, vol. LXIII, nr 4 (2014)

17. E.Bezak-Mazur, Specjacja w Ochronie i Inżynierii Środowiska (Komitet Inżynierii Środowiska PAN, Monografie, nr 20, Kielce, 2004) 
18. A.Hulanicki, Wspótczesna chemia analityczna. Wybrane zagadnienia (Wydawnictwo Naukowe PWN, Warszawa, 2001)

19. LAWA-Arbeitskreis, „Zielvorgaben” in Zusammenarbeit mit LAWA-Arbeitskreis „Qualitative Hydrologie der Fließgewässer”, Beurteilung der Wasserbeschaffenheit von Fließgewässern in der Bundesrepublik Deutschland - Chemische Gewässergüteklassifikation, Berlin (1998)

20. Rozporządzenie Ministra Środowiska z dnia 18 listopada 2014r. w sprawie warunków, jakie należy spełnić przy wprowadzaniu ścieków do wód lub do ziemi, oraz w sprawie substancji szczególnie szkodliwych dla środowiska wodnego (Dz.U. 2014 poz. 1800).

21. E.R.Long, D.D.Macdonald, S.l.Smith, F.D.Calder, Environmental Management 19, 1 (1995)

22. D.D.Macdonald, Approach to the assessment of sediment quality in Florida coastal waters, vol.1 - Development and evaluation of the sediment quality assessment guidelines, Report prepared for the Florida Department of Environmental Protection, Tallahasse, FL : 1-140 (1994)

23. Australian and New Zealand Environment and Conservation Council, ANZECC interim sediment quality guidelines, ANZECC Report for the Environmental Research Institute of the Supervising Scientist, Sydney, Australia (1997)

24. K.V. Heal, D.A. Hepburn, R.J. Lunn, Sediment management in sustainable urban drainage system ponds, Water Science \& Technology, Glasgow (2006)

25. Y.A. Yousef, L'Yu Lin, Win Lindeman, T. Hvitved-Jacobsen, The Science of the Total Environment 146/147 (1994) 